\title{
First report of Panstrongylus megistus sylvatic focus in municipality of Bambuí, state of Minas Gerais, Brazil
}

\author{
José Eloy dos Santos Júnior/ ${ }^{+}$, Liléia Diotaiuti, João Carlos Pinto Dias \\ Laboratório de Triatomíneos e Epidemiologia da Doença de Chagas, Instituto de Pesquisa René Rachou, \\ Fundação Oswaldo Cruz-Fiocruz, Av. Augusto de Lima 1715, 30190-002 Belo Horizonte, MG, Brasil
}

In 1943, the Center for the Study and Prophylaxis of Chagas Disease, Oswaldo Cruz Foundation, state of Minas Gerais $(M G)$, was created in the municipality of Bambui to carry out studies related to Chagas disease in the midwestern region of $M G$. Since that time, several investigations have been conducted to determine the natural habitat of triatomines, but Panstrongylus megistus colonies have never been found in this region. This paper records the first finding of a P. megistus sylvatic colony in 69 years of research. The characteristics of this ecotope and its implications for the epidemiology of Chagas disease are discussed.

Key words: Panstrongylus megistus - sylvatic ecotope - Bambuí - Chagas disease

The municipality of Bambuí is located in the mid-western region of the state of Minas Gerais (MG), $270 \mathrm{~km}$ from Belo Horizonte. This region has been the focus of many studies related to Chagas disease. After Chagas was first described (Chagas 1909), the next reports of the disease occurred between 1930-1941, with 25 acute cases described in four MG municipalities; 20 cases were in Bambuí. At that time, Panstrongylus megistus was the predominant vector, present in $75 \%$ of home infestations, followed by Triatoma infestans, at 25\% (Martins et al. 1942). In 1943, the occurrence of numerous cases of the disease prompted the founding of the Center for the Study and Prophylaxis of Chagas Disease (CEPMCh), Oswaldo Cruz Foundation/ MG, under the management of Dr Emmanuel Dias, who performed several studies on the epidemiology, diagnosis, clinical and prophylaxis of Chagas disease.

When CEPMCh was founded, T. infestans was already dominant in the households of the region, overwhelming the native $P$. megistus. Having observed the importance of the insect vector in the emergence of new cases of the disease, Dr Emmanuel Dias worked to develop methods for triatomine control. In the late 1940s, the use of gamma-benzene hexachloride (Gammexane ${ }^{\mathrm{TM}}$ ) led to an immediate reduction in acute cases and to the elimination of vector-borne Chagas disease in Bambuí by the early 1950s. Bambuí is recognised as a pioneer municipality in Chagas disease vector control in the Americas (Dias 1945, 1982, Dias \& Pellegrino 1948, Silveira 2000).

These activities led to the elimination of $T$. infestans, a non-autochthonous species last found in 1978. After T. infestans was successfully controlled, however, the

Financial support: CNPq, CPqRR/FIOCRUZ-MG

+ Corresponding author: santosjr_je@yahoo.com.br

Received 13 December 2010

Accepted 11 February 2011 native $P$. megistus began gradually to colonise homes and became the principal Chagas vector in the region, where it has persisted at low densities until today. The CEPMCh has since investigated the role of the sylvatic environment in the reinfestation process. These studies discovered Psammolestes tertius in Furnariidae bird nests and Rhodnius neglectus in palm trees, mainly in Acrocomia aculeata (macaúba). No T. infestans colony was found in the sylvatic environment, although nymphs of this species were observed in a Didelphis albiventris nest close to a residential area in Lagoa dos Monjolos, periurban area of Bambuí. The presence of adult $P$. megistus in the household environment was associated with shady ecotopes syvatics (Dias 1982).

This study aimed to identify the potential natural ecotopes of P. megistus and their role in the origin of household foci in Bambuí. To this end, nine field samplings were carried out between February 2008-May 2010. From Bambuí households with the highest number of notifications and proximity to residual natural vegetation were identified through Chagas Disease Control Program (PCDCH) data. These residences were investigated for the presence of triatomines in home environment and in the potential sylvatic habitats.

Peri-domiciliary and domiciliary areas were actively searched with the aid of flashlights and tweezers and the sylvatic environment was examined both by direct search in palm trees and other shelters and by seeking opossum nests by the spool-and-line technique (Miles 1976) with reels made of cylindrical plastic pots using Kooban $^{\text {TM }}$ line (Santos-Jr 2007). To evaluate possible natural reservoirs of Trypanosoma cruzi, small mammals were captured and checked for Chagas infection by xenodiagnosis and blood culture. Opossum burrows found by the spool-and-line technique were investigated using Noireau traps (Noireau et al. 2002), flashlights, tweezers and pirisa (a flushing-out agent). Material from inside the burrow was collected for screening in the laboratory. Temperature $(\mathrm{T})$ and relative humidity $(\mathrm{RH})$ inside the burrows and in the surrounding environment 
was monitored with HOBO H8 data loggers (Onset Computer Corporation) programmed to take readings every 15 min and data were processed using the Boxcar Pro 4.3 program. This study was carried out in accordance with Brazilian law (IBAMA written authorisation 16217$3 / 2008$, CEUA P-0502/08). Using the data obtained in the PCDCH, it was possible to compare two distinct periods for P. megistus: 1974-1980 and 2005-2010 (Fig. 1). The reduction in the number of positive locations over the years is likely related to a large reduction in the number of notifications and a decrease in the dispersal of the species. Sylvatic habitats in 13 rural localities in Bambuí were also searched; these areas were chosen because they are close to houses where the presence of triatomines has previously been reported. We investigated 123 different natural ecotopes, in which Noireau traps were set daily. Material from these ecotopes (such as branches and leaves) was also collected when possible. In $\mathrm{A}$. aculeata (macaúba) palm trees, which are abundant in the area, uninfected $R$. neglectus were found in caatinga

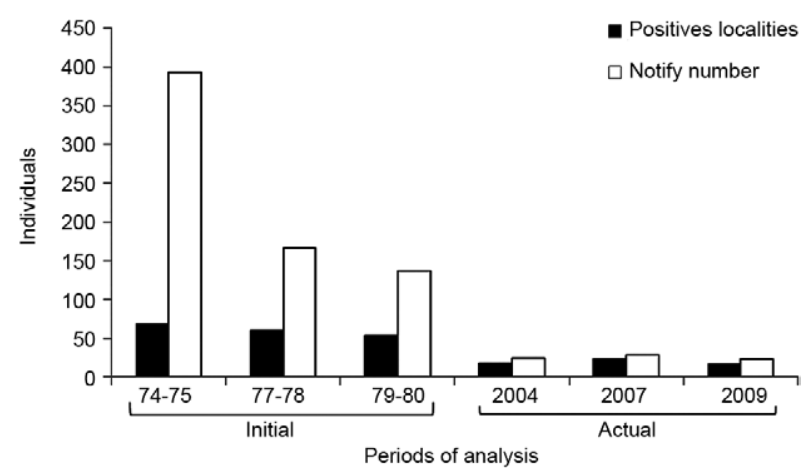

Fig. 1: triatomine reports and localities positive for Panstrongylus megistus in the municipality of Bambuí, state of Minas Gerais, in two periods of the Chagas Disease Control Program at the beginning of the epidemiological surveillance phase and in the last decade.

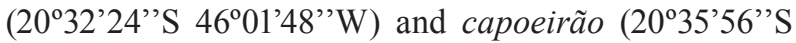
$\left.46^{\circ} 36^{\prime} 19^{\prime \prime} \mathrm{W}\right)$. A natural focus of $P$. megistus was detected in only one ecotope (20'11'01''S $\left.46^{\circ} 32^{\prime} 12^{\prime \prime} \mathrm{W}\right)$ : a living tree (Dimorphandra mollis Benth, popularly known as faveira) with a large natural hollow, in the village of Olhos D'água in May 2010 (Table). The tree contained nymphs and hatched eggs of triatomines; the nymphs were captured with the aid of the Noireau traps and the eggs by screening the material collected in the tree. Also found at the site were small lizards, a bat, and a large quantity of rodent and $D$. albiventris faeces, indicating that the tree was in frequent use as shelter for these wild animals (Fig. 2). Because P. megistus had not been reported in the area or in households in the last two years, the colony was characterised as sylvatic. The HOBO sensor was left installed inside the hollow tree for five days, with one sensor outside as a reference; results show a more constant $\mathrm{T}$ and $\mathrm{RH}$ inside the tree. Over the course of sampling in Bambuí, 74 wild or synanthropic animals, marsupials and rodents were collected. In sylvatic habitats surrounding the village of Olhos D'água, the following were captured: two marsupial species, $D$. albiventris (5) and Micoureus sp. (7) and three rodent species, Nectomys sp. (8), Oecomys sp. (2) and Mus musculus (1). No T. cruzi infection was detected in the captured animals or in the P. megistus nymphs. This area was searched because a female $P$. megistus had been found inside a house and vestiges of triatomine feces in the barn, which was also used as a henhouse five months previously. The natural focus was $54 \mathrm{~m}$ away from the house and the female most likely laid eggs in the natural environment before entering the building. According to Schlemper-Jr et al. (1985), triatomine sylvatic foci in the state of Santa Catarina were found between 15-300 $\mathrm{m}$ from the nearest residences, favouring incursions by adult triatomines. The discovery of $P$. megistus nymphs, rather than adults, is in agreement with the findings of Dias and Dias (1968), who found a greater abundance of early-stage nymphs between April-June, corresponding to oviposition in the late summer, when the number of adult insects in houses is

TABLE

Natural ecotopes investigated in 13 localities of municipality of Bambuí, state of Minas Gerais, indicating the triatomine ${ }^{a}$ foci found

\begin{tabular}{|c|c|c|c|}
\hline Ectopes investigated & $\begin{array}{l}\text { Quantity } \\
\text { (\%) }\end{array}$ & $\begin{array}{l}\text { Ectopes } \\
\text { positives }\end{array}$ & Triatomine foci \\
\hline Hollow trees and anfractuosities & $46(37)$ & $1 / 46$ & $\begin{array}{c}\text { Panstrongylus megistus } \\
\text { (4 nymphs of } 2 \text { th and 3th stages and } 4 \text { hatched eggs) }\end{array}$ \\
\hline Burrows in the floor & $25(20)$ & - & - \\
\hline Palms (Acrocomia aculeata) & $21(17)$ & $3 / 21$ & $\begin{array}{c}\text { Rhodnius neglectus } \\
(1 \bigcirc, 1 \delta \text { and } 2 \text { nymphs of } 4 \text { th stage })\end{array}$ \\
\hline Bird nests & $15(12)$ & - & - \\
\hline Trellis of lianas & $10(8)$ & - & - \\
\hline Rock shelters & $6(5)$ & - & - \\
\hline Total & 123 & - & - \\
\hline
\end{tabular}

a: no triatomine showed Trypanosoma cruzi infection. 
also reduced. Environmental parameters of the sylvatic focus of $P$. megistus showed smaller variations in $\mathrm{T}$ ( $\mathrm{T}$ $\left.=11 \pm 1^{\circ} \mathrm{C}, \max =15^{\circ} \mathrm{C}, \min =9^{\circ} \mathrm{C}\right)$ and $\mathrm{RU}(\mathrm{RU}=88 \pm$ $4 \%, \max =95 \%, \min =62 \%)$ inside the breeding sites in comparison with the external conditions $\left(\mathrm{T}=12 \pm 6^{\circ} \mathrm{C}\right.$, $\max =24^{\circ} \mathrm{C}, \min =4^{\circ} \mathrm{C} ; \mathrm{RU}=78 \pm 16 \%, \max =94 \%$, $\min =41 \%$ ). This damping effect probably provides greater protection for the triatomines, especially for early nymphs, and maintains relatively high humidity. The average $\mathrm{RH}$ in the sylvatic site remained close to the maximum observed. Pires (2003) showed that an RH of $73 \%$ leads to optimal rates of egg hatching and nymphal moulting in P. megistus. Since this species originates from the humid climate of the Atlantic Forest area, dryness may be a limiting factor for the dispersal of this species in Brazil (Forattini 1980, Cortez et al. 2007). Sylvatic P. megistus have been found in other Brazilian states, where they are often associated with nests of Didelphis sp. and show a preference for arboreal habitats (Fig. 3). Although the opossums tested here were not infected, Fernandes et al. $(1991,1994)$ demonstrated that these reservoirs play an important role in the interaction of the parasite's domestic and sylvatic cycles in Bambuí. Wildlife reservoirs are involved in the maintenance of T. cruzi in the natural environment and in its dispersal to domestic environments. The low frequency of natural triatomine colonies observed in the municipality corroborates the low numbers of domiciliary colonies currently reported. The reduction in triatomine colonies in households is attributed mainly to the extensive vector control program that has been established for decades in Bambuí. However, unlike T. infestans, which is restricted to the household environment in Brazil, P. megistus has a wide distribution in nature and frequently moves

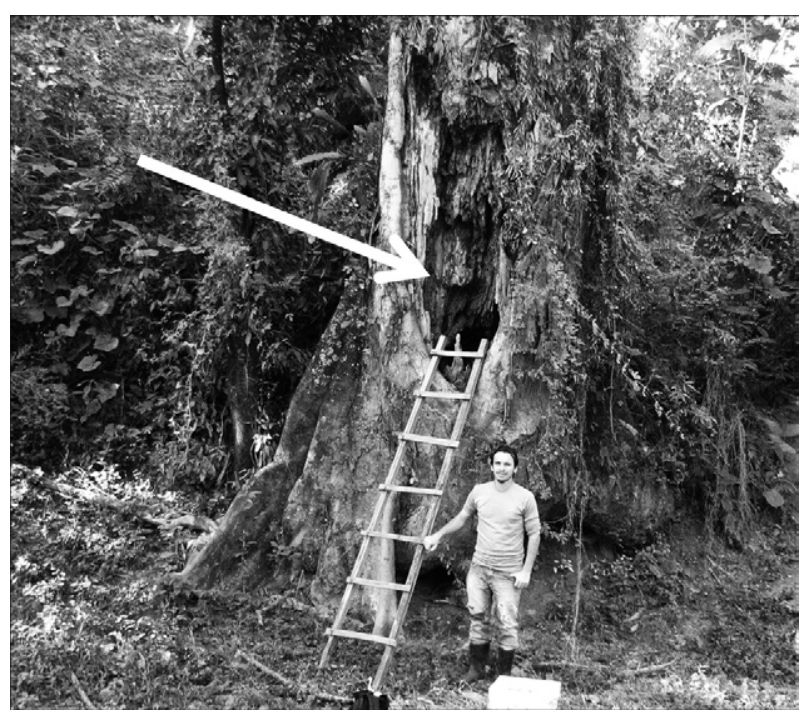

Fig. 2: natural ecotope of Panstrongylus megistus found in the municipality of Bambuí, state of Minas Gerais, Brazil (the white arrow indicates the entrance of the hollow). between natural ecotopes and dwellings (Dias 1982, Fernandes et al. 1994). The low rates of re-infestation (10\%) and domiciliary colonies $(20 \%)$ observed in residences evaluated between 2004-2009 suggest that the sylvatic environment is the main source of household recolonisation. The expansion of monocultures such as beans, corn and especially sugarcane has reduced the original vegetation in the municipality over recent decades. Such land use change has led to a reduction in the natural resources used as shelter and food by the triatomines; these resources previously supported high rates of domestic invasion (Forattini et al. 1978). In an epidemiological study in Bambuí, Fernandes et al. (1992) observed that $P$. megistus captured inside dwellings showed higher feeding preference for humans and dogs and warned that vector-borne Chagas disease in the municipality could resurge if the triatomine control program were interrupted. The data presented here suggest that even with a low rate of infestation in sylvatic habitats, the colonisation of domiciliary environments has been extensive and ongoing throughout the municipality. We conclude that an active surveillance program is necessary to contain household infestations.

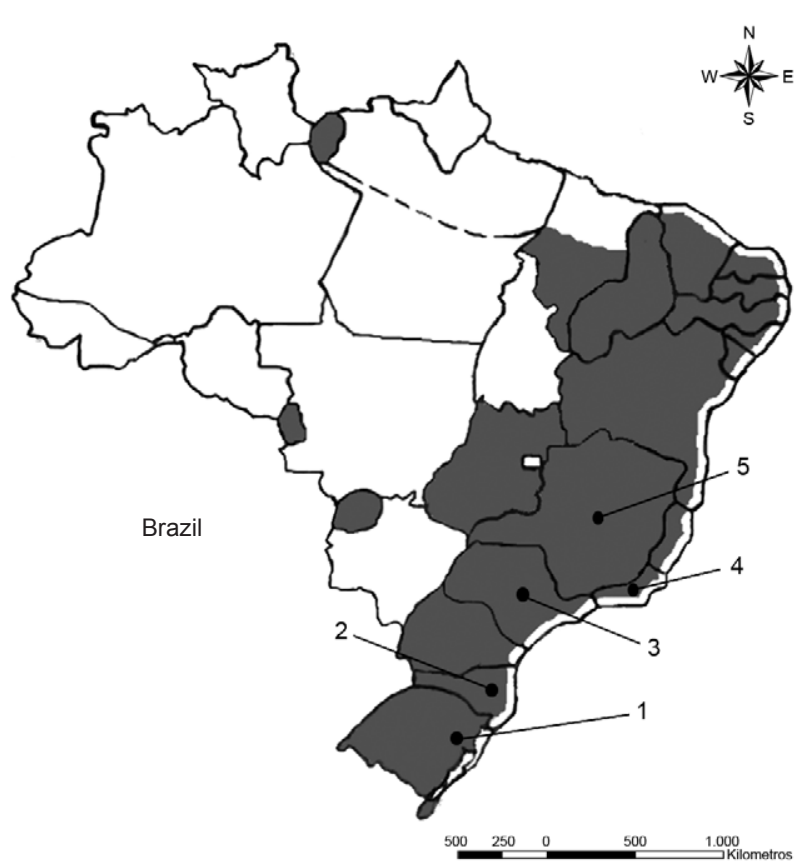

Fig. 3: map of Panstrongylus megistus distribution (area in gray) [modified from Carcavallo et al. (1999)] and the principal findings of sylvatic foci in different Brazilian states. 1: state of Rio Grande do Sul (hollow trees) (Santos-Jr 2007); 2: state of Santa Catarina (hollow trees and Bromeliaceae) (Leal et al. 1961, Schlempler-Jr et al. 1985, Grisard et al. 2000); 3: state of São Paulo (hollow trees, anfractuosities, bromeliads, palms and rock shelters) (Barretto et al. 1964, Barretto 1967, Forattini et al. 1970, 1977, 1978); 4: state of Rio de Janeiro (hollow trees) (Miles et al. 1982); 5: state of Minas Gerais (hollow trees, tree holes, palms and burrows in the floor) (Barretto et al. 1978, Neves 1979, Santos-Júnior et al. 2011, the present paper). 


\section{ACKNOWLEDGEMENTS}

To Ronaldo M de Melo, Paulo A Lamounier, Ascânio Lamounier and Catarina Macedo, for the constant support and suggestions in field works, to Dr Christopher Schofield, for the criterious revision and suggestions for this paper, and to Christiane Santos Matos, for the personal involvement during this project.

\section{REFERENCES}

Barretto MP, Ribeiro RD, Rocha GM 1978. Estudos sobre reservatórios e vectores silvestres do Trypanosoma cruzi. LXIX: inquérito preliminar sobre triatomíneos silvestres na região do Triângulo Mineiro, MG, Brasil. Rev Bras Biol 38: 633-637.

Barretto MP, Siqueira AF, Pedreira de Freitas JL 1964. Estudo sobre reservatórios e vetores do Trypanosoma cruzi. II - Encontro do Panstrongylus megistus em ecótopos silvestres no estado de São Paulo (Hemiptera, Reduviidae). Rev Inst Med Trop Sao Paulo 6: 56-63.

Carcavallo RU, Curto de Casas SI, Sherlock IA, Galíndez Girón I, Jurberg J, Galvão C, Mena Segura CA, Noireau F 1999. Geographical distribution and alti-latitudinal dispersion. In RU Carcavallo, I Galíndez Girón, J Jurberg, H Lent (eds.), Atlas of Chagas' disease vectors in the America, vol. III, Fiocruz, Rio de Janeiro, p. 747-792.

Chagas CRJ 1909. Nova tripanosomíase humana. Estudos sobre a morphologia e o ciclo evolutivo do Schizotrypanum cruzi $\mathrm{n}$. gen. n. esp., agente da nova entidade mórbida do homem. Mem Inst Oswaldo Cruz 1: 159-218.

Cortez MR, Avalos M, Rocha V, Gorla D 2007. Distribución biogeográfica de los triatominos in Bolivia. In MR Cortez, Triatominos de Bolivia y la enfermedad de Chagas, Ministerio de Salud y Deportes, Programa de Chagas, Imprenta Genesis, La Paz, p. 67-137.

Dias E 1945. Um ensaio de profilaxia da doença de Chagas, Imprensa Nacional, Rio de Janeiro, 116 pp.

Dias E, Dias JCP 1968. Variações mensais da incidência das formas evolutivas do Triatoma infestans e do Panstrongylus megistus no município de Bambuí, estado de Minas Gerais (II ${ }^{\mathrm{a}}$ Nota: 1951 a 1964). Mem Inst Oswaldo Cruz 66: 209-226.

Dias E, Pellegrino J 1948. Alguns ensaios com o "Gammexane" no combate aos transmissores da doença de Chagas. Bras Medico 62: 185-191.

Dias JCP 1982. Doença de Chagas em Bambuí, Minas Gerais, Brasil: estudo clínico-epidemiológico a partir da fase aguda, entre 1940 e 1982, PhD Thesis, Universidade Federal de Minas Gerais, Belo Horizonte, 376 pp.

Fernandes AJ, Chiari E, Casanova C, Dias JCP, Romanha AJ 1992. The threat of reintroduction of natural transmission of Chagas' disease in Bambuí, Minas Gerais state, Brazil, due to Panstrongylus megistus. Mem Inst Oswaldo Cruz 87: 285-289.

Fernandes AJ, Chiari E, Rodrigues RR, Dias JCP, Romanha AJ 1991. The importance of the opossum (Didelphis albiventris) as a reservoir for Trypanosoma cruzi in Bambuí, Minas Gerais state. Mem Inst Oswaldo Cruz 86: 81-85.

Fernandes AJ, Diotaiuti L, Dias JCP, Romanha AJ, Chiari E 1994. Inter-relações entre os ciclos de transmissão do Trypanosoma cruzi no município de Bambuí, Minas Gerais, Brasil. Cad Saude Publica 10: 473-480.

Forattini OP 1980. Biogeografia, origem e distribuição da domiciliação de triatomíneos no Brasil. Rev Saude Publica 14: 265-299.

Forattini OP, Ferreira AO, Silva EOR, Rabello EX 1978. Aspectos ecológicos da tripanossomíase americana. XII - Variação regional da tendência de Panstrongylus megistus à domiciliação. Rev Saude Publica 12: 209-233.

Forattini OP, Ferreira OA, Silva EOR, Rabello EX 1977. Aspectos ecológicos da tripanossomose americana. VIII - Domiciliação de Panstrongylus megistus e sua presença extradomiciliar. Rev Saude Publica 11: 73-86.

Forattini OP, Rabello EX, Castanho MLS, Pattoli DGB 1970. Aspectos ecológicos da tripanossomose americana. I - Observações sôbre Panstrongylus megistus e suas relações com focos naturais da infecção em área urbana da cidade de São Paulo, Brasil. Rev Saude Publica 4: 19-30.

Grisard EC, Carvalho-Pinto CJ, Scholz AF, Toma HK, Schlemper BR Jr, Steindel M 2000. Trypanosoma cruzi infection in Didelphis marsupialis in Santa Catarina and Arvoredo Islands, Southern Brazil. Mem Inst Oswaldo Cruz 95: 795-800.

Leal H, Ferreira Neto JA, Martins CM 1961. Dados ecológicos sôbre triatomíneos silvestres na Ilha de Santa Catarina (Brasil). Rev Inst Med Trop Sao Paulo 3: 213-220.

Martins AV, Versiani V, Tupynambá AA 1942. Sobre 25 casos agudos da moléstia de Chagas observados em Minas Gerais. Mem Inst Ezequiel Dias 3-4: 1-6.

Miles MA 1976. A simple method of tracking mammals and locating triatomine vectors of Trypanosoma cruzi in Amazonian forest. Am J Trop Med Hyg 25: 671-674.

Miles MA, Souza AAA, Póvoa MM 1982. O ecótopo de Panstrongylus megistus (Hemiptera, Reduviidae) na floresta do Horto (Rio de Janeiro). Rev Bras Biol 42: 31-35.

Neves DP 1979. Aspectos da dinâmica populacional do Panstrongylus megistus (Hemiptera, Reduviidae) em condições de campo e laboratório, PhD Thesis, Universidade Federal de Minas Gerais, Belo Horizonte, 121 pp.

Noireau F, Abad-Franch F, Valente SAS, Dias-Lima A, Lopes CM, Cunha V, Valente VC, Palomeque FS, Carvalho-Pinto CJ, Sherlock I, Aguilar M, Steindel M, Grisard EC, Jurberg J 2002. Trapping Triatominae in silvatic habitats. Mem Inst Oswaldo Cruz 97: 61-63.

Pires HHR 2003. Aspectos do comportamento do Panstrongylus megistus (Burmeister, 1835), PhD Thesis, Instituto Oswaldo Cruz/Fiocruz-RJ, Rio de janeiro, 109 pp.

Santos-Jr JE 2007. Avaliação da preferência alimentar e da infecção por Trypanosoma cruzi (Chagas, 1909) em Panstrongylus megistus (Burmeister, 1835) num fragmento de floresta em Porto Alegre, RS, MSc Thesis, Porto Alegre, $54 \mathrm{pp}$.

Schlemper-Jr BR, Steindel M, Gargioni R, Farias CJM, Oliveira R, Trianon JAX 1985. Reservatórios e vetores silvestres do Trypanosoma cruzi e suas relações com o domicílio humano na Ilha de Santa Catarina. Arq Cat Med 14: 91-96.

Silveira AC 2000. Profilaxia. In Z Brener, Z Andrade, M Barral-Neto, Trypanosoma cruzi e doença de Chagas, 2nd ed., GuanabaraKoogan, Rio de Janeiro, p. 75-87. 